\title{
Potential Of Best Management Practices (Bmps) Projects For Effective Integrated Water Resource Management
}

\author{
Anis Syazwani Sukereman, Robiah Suratman* \\ Department of Real Estate, Universiti Teknologi Malaysia, 81310 UTM Johor Bahru, Johor, Malaysia \\ *Corresponding author: robiah@utm.my
}

\begin{abstract}
Nowadays, water pollution was viewed as a crucial issue and if not properly managed, it can threaten human health along with environment. Being so, various efforts have been taken by the government of Malaysia to ensure the Integrated Water Resource Management can be effectively implemented. In supporting the effective implementation of this approach, a Best Management Practices (BMPs) projects were carried out. Unfortunately, the implementation of these projects still remains in doubt and was unfamiliar by many parties. Therefore, this paper examined the outcome of BMPs Projects in the perspective of river water quality in Malaysia. By using content analysis technique towards 12 year period of data from the Malaysia Environmental Quality Report, starting from year 2002 to the year 2014, four projects were selected in order to identify is there any difference, especially on the river water quality status before and after BMPs Project have been carried out. The result of the studies revealed that, the BMPs projects have a potential in improving water quality status and there is a need to actively promote this project to the various stakeholders involved so that it can minimize Integrated Water Resource Management issues as well as enhancing the implementation.
\end{abstract}

Keywords: Best management practices project; integrated water resource management; implementation; water quality

(C) 2016 Penerbit UTM Press. All rights reserved

\subsection{INTRODUCTION}

Water is a vital resource and plays a significant role that sustains life on earth. Any changes in the natural quality and distribution of water can sometimes be catastrophic on environmental impacts. Presently, there were a lot of environmental issues regarding water pollution in Malaysia (Jacky Ling Kuo Bao, 2010). Water quality of many rivers has been affected due to rapid development in recent years. For instance, the number of clean rivers within the period of eight years has decreased from 338 in 2005 to 275 in 2013 while the number of slightly polluted rivers has increased from 156 in 2005 to 173 in 2013 (Malaysia Environmental Quality Report, 2013). Consequently, it shows that access to clean river water becomes a critical issue to overcome by the government and as a result, the study and management of freshwater resources is becoming more challenging in this country (Aris et al. 2014). In the past, substantial efforts have been made to review the freshwater ecosystem of environmental conditions in Malaysia and some studies have devoted on the hydrological property assessment and water quality (Yusof et al., 2001, Suratman, Ali, and Lo, 2005, Gasim et al., 2007, Shuhaimi-Othman et al., 2007, Fulazzaky et al., 2010, Suratman et al., 2009). From those studies, researchers concluded that the surrounding areas of freshwater could be environmental damage due to unsustainable development (Aris et al. 2014). In addition, Muyibi et al. (Muyibi et al. proved that the development activities had induced the water pollution problem in Malaysia.

As comprehend the seriousness of the threat that posed to river water, Malaysia has made significant efforts to improve the river water quality through active implementation of Integrated Water Resource Management (IWRM) since 2002. IWRM has gained global recognition as the recommended approach to help countries achieve solutions to water crisis management (Sukereman and Robiah, 2014) as well with achieving more effective management of increasingly scarce water resources. Hitherto, many countries have accepted and adopted IWRM as an action plan for sustainable water management. Based on the result of UN-Water Survey of progress on IWRM, where the total number of countries that responded was increased from 104 countries on 2008 to 134 countries in 2012 (UNEP, 2012 ), it is proved that IWRM has now been accepted internationally. In regards of that, a number of international and national development organizations have persisted to support for its implementation.

Global Water Partnership (GWP) (2004) also stated that Malaysia is one of the countries that has presented some steps towards IWRM Plan implementation and has adopted and continuously implemented IWRM principles in the development and management of its water resources.

Therefore, in supporting the effective implementation of IWRM in Malaysia, Best Management Practices (BMPs) projects was carried out with the headed by the Government of Malaysia through the Economic Planning Unit and Department of Drainage and Irrigation assisted by Dr. Nik \& Associates Sdn. Bhd. (DNASB) along with Asia Pacific Environmental Consultant Sdn. Bhd. (ASPEC). The duration of this BMPs project was held in four years from 2009 until 2012.

However, Buller (1996) and Margerum and Hooper (2001) concluded that, the implementation of BMPs concept at the local level can be extremely challenging and this scenario has been experienced by river managers in Malaysia (Donoso and Kansino, 2010). In addition, Rahaman and Varis (2005), also stated that one of the major challenges that hindering the effectiveness of IWRM implementation 
is due to the absence of any successful case or project evidence that does not clearly show achievement of the IWRM outcome, (Kua, 2007) indeed it highlights a number of challenges (Varis et.al., 2006).

Therefore, this paper examined the outcome of Best Management Practices (BMPs) Projects in enhancing IWRM effective implementation by focusing on river water quality in Malaysia. In its attempt to present this perspective, this paper will explain the background of BMPs project in IWRM implementation, the development of BMPs project within four selected cases which are Sungai Langat, Sungai Melaka, Sungai Miri and Sungai Trusan, key criteria for selecting BMPs projects as obtained from the existing literature and presenting the trend of the river water quality status of the BMPs projects through review of twelfth years of Malaysia Environmental Quality Report from 2002 until 2014. Finally, this paper concludes the outcome of the BMPs project in terms of river water quality status as well as highlights its potential for enhancing the effective implementation of IWRM in Malaysia.

\subsection{THEORETICAL FOUNDATION OF THE STUDY}

In general, compared to any other technique, method or process, Best Practice emphasize that there is a technique, method, process, activity, incentive or reward that is more effective at delivering a particular outcome (Medema et al., 2008). It is hoped that with this idea, a desired outcome can be delivered with fewer problems and unforeseen complications with proper processes, checks, and testing. Apart from that, best practices can also be elaborate as the most efficient and effective way of succeeding a task, based on recurrent procedures that have proven themselves over time.

Meanwhile, as mentioned by the World Water Assessment Program (Nik and Asia, 2008a) 'Best Practice' can be defined as good examples of IWRM at the river basin level in the form of case studies that illustrating actual IWRM efforts and 'Extracted Key for Success' in enhancing IWRM implementation. Nowadays, the idea of transferring 'best practice' has become one of the trends in water management Sonada, 2009). This trend was made based on the development of pilot projects to be used as a key reference in determining the key success or failure to implement the IWRM in an effective way. For instance, developed countries most often transfer their model of successful river basin management institution to another river basin context in other developed countries.

Despite of this idea bring good intentions, most of the literature, including reviews of actual experiences, state that this assumption requires a deeper and critical considerationand not as simple as it seems to be (Wongprasong, 2007). However, Malaysia had presented some step forwards in building up their BMPs project as pilot project reference so that it can fill the gap on how to enhance the effective IWRM implementation. Therefore, apart from the definition mentioned above, the suit Best Management Practices (BMPs) project's definition to be used in this study can be defined as show cases or demonstration projects that target to eventually prepare the guidelines of IWRM implementation (Svenden, 2005).

\section{Development of BMPs Projects within four selected case}

Currently, there are eleven BMP projects that have been selected and covering all aspects of IWRM issues as shown in Table 1 (Nik and Asia, 2008b). This study more focuses on the potential of BMPs on river water quality. Therefore, only four projects will be examined and suitable to be explored due to the availability of the river water quality data which are Sungai Langat, Selangor; Sungai Melaka; Sungai Miri, Sarawak and Sungai Trusan, Sarawak.

Table 1 List of Best Management Practices (BMPs) projects of effective IWRM implementation

\begin{tabular}{|c|c|c|}
\hline NO. & STATE & PROJECT \\
\hline 1. & Sabah & $\begin{array}{l}\text { Water Quality improvement through pesticide } \\
\text { control in Sungai Liwagu, } \\
\text { Kundasang, Sabah }\end{array}$ \\
\hline 2. & $\begin{array}{l}\text { Negeri } \\
\text { Sembilan }\end{array}$ & Use of wet detention ponds as community parks \\
\hline 3. & $\begin{array}{l}\text { Pulau } \\
\text { Pinang }\end{array}$ & Nega-litres" demonstration project \\
\hline 4. & Sarawak & Sg. Miri River Basin Stakeholders Community \\
\hline 5. & Melaka & $\begin{array}{l}\text { River adoption and riverine corridor management of } \\
\text { Sg. Pengkalan, Alor } \\
\text { Gajah, Melaka }\end{array}$ \\
\hline 6. & Pahang & $\begin{array}{l}\text { Urban river corridor management along } \mathrm{Sg} \text {. } \\
\text { GalingBesar, Kuantan, Pahang }\end{array}$ \\
\hline 7. & Pahang & $\begin{array}{l}\text { Poverty Alleviation and Economic Capacity Building } \\
\text { of Local Communities in TasikChini Wetlands, } \\
\text { Pahang }\end{array}$ \\
\hline 8. & Selangor & $\begin{array}{l}\text { Identification and Management of Water-borne } \\
\text { diseases in a riverine } \\
\text { community in Sg. Langat, Selangor ( } \mathrm{R} \& \mathrm{D} \text { Project) }\end{array}$ \\
\hline 9. & Sarawak & $\begin{array}{l}\text { Framework for National Biodiversity Action Plan - } \\
\text { Pilot project to develop the Local Biodiversity } \\
\text { Action Plan for the Ba Kelalan area in Sg. Trusan } \\
\text { catchment, Sarawak }\end{array}$ \\
\hline 10. & Kuala & River Water Quality Improvement through \\
\hline & Lum & $\begin{array}{l}\text { Determination of EnvironmentalFlows ( } \mathrm{R} \& \mathrm{D} \\
\text { Project) }\end{array}$ \\
\hline 11. & Kelantan & $\begin{array}{l}\text { Groundwater Management for Kota Bharu Aquifer, } \\
\text { Kelantan }\end{array}$ \\
\hline
\end{tabular}


The overviews on four selected cases of BMPs project are briefly discussed below:

\section{a) Sungai Melaka, Melaka (Nik and Asia, 2008c)}

Sungai Melaka is the main river in the state of Melaka that has contributed tremendously towards the past, present and expected future development of the state. Besides serving as the main source of potable water supply for the Melaka State and the main flood channel, it has also been a source of irrigation water supply, food

supply, river transportation channel, recreation centers as well as tourism attraction.

Rapid development in the catchment area had contributed to the deterioration of the river water quality and its environment. It is no more a natural recreational center for the local residents. The federal and state Governments have initiated and undertaking various steps and effort to rehabilitate and beautify certain stretches of the river.

The proposed project site covers the upper stretch of Sungai Melaka near Alor Gajah town and KampungPengkalan. At the proposed site, it has a catchment area of about $30 \mathrm{sq}$. $\mathrm{km}$ that can be easily accessible via the Alor Gajah/Melaka road. Currently, the river has fairly wide river reserve and is in fairly natural state with a historical old irrigation headwork. The river water quality appears to be deteriorating due to siltation and pollution from urban storm water discharges, land clearing, rubbish dumping, workshops and etc. There are several villages and residential settlement around the areas with limited recreational facilities nearby.

This BMPs project of Sungai Melaka aim to develop a community ownership program among local community and stakeholders through participation in river adoption activities, encourage political advocacy in IWRM implementation, raise the awareness and capacity building in IWRM implementation and develop documented guidelines for community-based river corridor management program through smart partnership between local residents, relevant stakeholder and government agencies.

\section{b) Sungai Langat, Selangor (Nik and Asia, 2008d)}

With $120 \mathrm{~km}$ long, Sungai Langat is originates from the Main Range, draining westwards to the Straits of Malacca. Various agricultural and industrial activities were identified along the river which dischargewastes into this river.

The proposed Project site is within the industrialized areas of Bukit Changgang, OlakLempit, and LabohanDagang estates and is reachable via the Nilai-Banting highway. These are the areas of dense housing and comprise wood-based, electronic and steel industries, oil palm and rubber plantations. As the location of the project is at the downstream and most polluted part of Sg Langat, the outbreak of infectious diseases, particularly food-borne, vector-borne and water-borne diseases remain a public health concern not only among the riverine communities in the area but also to the inhabitants downstream of this industrial zone. In addition, the usage of contaminated water for recreation can also lead to health issues; for instance skin diseases, eye infections and worm infestation.

The objectives of this project are to plan for a community-based baseline on the communities most vulnerable to water-borne and water-related health matters. Besides, it is hope that this project can actively engage community groups including local residents, NGOs, private sectors and special interest groups for the aim of prevention and control of water-related diseases and health risks in Malaysia and investigate contributory causes of the industrial effluents, followed by identification of preventive strategies and BMPs through education, self-help and community mobilization.

\section{c) Sungai Miri, Sarawak (Nik and Asia, 2008e)}

Miri is one of the 4 local councils in Malaysia that has implemented the Local Agenda 21 (LA21) program. As part of the LA21 program, 3 working groups has been set-up, comprising of both institutional and community stakeholders, to implement the LA21 program in Miri. The 3 groups are: i) River pollution group, ii) Drainage group and iii) Solid waste reduction group.

Lack of recognition by the state authorities that there is a need to address the problems identified by the 3 working groups in Miri from a "River Basin Perspective" is one of the common issues. This is due to the areas covered by the Miri City Council forms only the lower part of the Sg. Miri river basin. While, the river pollution, drainage and the solid waste floating problem in Sg. Miri, requires the LA21 groups to address the problem from a river basin perspective.

Therefore, the project aims to create the Sg. Miririver basin stakeholder groups and document the process of capacity building of the groups to act as river basin stakeholders within the institutional framework of an integrated river basin management.Besides, in supporting integrated river basin management through the setting-up of a website for the group, it is hoped that an awareness of its activities can be created.

\section{d) Sungai Trusan, Sarawak (Nik and Asia, 2008f)}

The BatangLemanakcatchment, has features which are common to the catchments of many of the river systems in the interior zone of Sarawak. These features include the terrains and soil types, land use, socio-economic cultural settings, biodiversity, landscape curved out by the shifting cultivation of hill paddy, the dependence of the local people on the biodiversity to sustain their livelihood and other features. As such, the proposed pilot project to develop the local biodiversity action plan for BatangLemanak catchment can be a model for other catchments which have similar features.BatangLemanak is one of three tributaries of BatangLupar; the other two being Batang Ai and BatangSekerang. The BatangLemanak catchment lies in the Engkilili Sub-District and the total area is estimated to be approximately 61,460 ha.

The northern end of the BatangLemanak catchment is linked to the south-western portion of the Lanjak-Entimau Wildlife Sanctuary. A narrow strip of rugged land at the northern end of the catchment forms a part of the buffer zone for the Sanctuary. The southwestern and south portions of the Sanctuary drain into Sungai Skrang, Sungai Lemanak, and Batang Ai, the three main tributaries of BatangLupar. 
Therefore, in line with the National Biodiversity Policy at BatangLemanakcatchment, which was endorsed by the Cabinet in October 1997, it is hoped that this project candevelop and implement a local biodiversity plan also formulate biodiversity management plan, awareness and capacity building programs.

\subsection{KEY CRITERIA OF BEST MANAGEMENT PRACTICES (BMPs) PROJECTS}

In order to ensure the effective implementation of IWRM, theseven following key criteria or basis are used in the identification and selection of the IWRM BMP project (Nik and Asia, 2008g).

\section{a) IWRM Thematic Areas (issues)}

BMP project must be a good range and suit to IWRM issues. The connection of this range should ideally be in accordance with the IWRM thematic areas and there are eleven of IWRM issues that have been identified as shown in Table 2 (Nik and Asia, 2008h).

Table 2 Key issues on IWRM

\begin{tabular}{cl}
\hline NO. & \multicolumn{1}{c}{ KEY IWRM ISSUES } \\
\hline 1. & River Water Quality \\
2. & Catchment and Land Use Management \\
3. & Flooding \\
4. & Potable water Supply \\
5. & Institutional Arrangements \\
6. & Segmented Management Approach \\
7. & River Corridor/Riparian Management \\
8. & Wetlands management \\
9. & Water Borne Diseases \\
10. & Biodiversity \\
11. & Droughts \\
12. & Environmental Flow \\
13. & Ground Water Management \\
\hline
\end{tabular}

b) Regional Representation (North, Central, East \& South Peninsular Malaysia,Sarawak \& Sabah)

Regional representation for this BMP project must include an overall of Malaysia that cover Peninsular Malaysia, Sabah and Sarawak. Peninsular Malaysia can be sub-divided into 4 regions which are North, Central, East and South. Perlis, Kedah, Penang and Perak will cover the Northern region. Meanwhile, the Eastern region shall cover the states of Kelantan, Terengganu and Pahang. Selangor, Federal territories of Kuala Lumpur and Putrajaya shall cover the Central region whereas the Southern region shall cover the states of Negeri Sembilan, Melaka and Johor.

c) Stakeholder Representation (Various Sectors \& Groups).

Proposed BMP projects should also havegood types of stakeholder representation in the working committees suchinstitutional, business, NGO and community. The institutional stakeholder group will comprise of government agencies and educational institutions while the business stakeholder group will comprise of all business organizations. The NGO group will cover all special interest community groups, apart from political organization, whereas JKK and residents associations, which will be covered by the community stakeholder group.

\section{d) Key Stakeholders (Project ownership) Commitment}

There must be one or two key stakeholders who are committed to own the BMP project and be responsible to implement the project due to subsequent funding. This is very essential to ensure the sustainability of the project once it is completed, as ownership must rest with a stakeholder and not with the consultant who may be engaged to assist the implementation of the project.

\section{e) Past track records (key stakeholders) in existing or similar projects}

There is a need to identify and work with stakeholder groups that working to address similar issues in existing or similar projects, in the proposed BMP project locations. This will ensure rapid development of the BMP project proposals and subsequent commitment for the successful implementation of the BMP projects, if they are approved for funding by the government.

\section{f) Smart partnership and "seed funding"}

There should be a strong emphasis on smart partnership between the 4 stakeholder groups - institutional, business, NGO and the community. An ideal BMP should influence on the key contributions that each stakeholder can bring to the partnership. For instance, 
the institutional can support to give official status to the project, while the business can contribute to financial and the NGO with the community can contribute for their ideas, energy and commitment to the project.

Funding for the BMP projects should, ideally, be basedon the concept of "seed funding" to ensure sustainability.For matching funds, the fund should act as a catalyst to be given to the project by institutional and businessstakeholders, couple with the contribution-in-kind by the NGO and communitystakeholders. Once the "seed fund" has been used up to demonstrate the feasibility and success of the BMP project, it should have the potential to be able to protect, subsequent funding to sustain the project, to be a good BMP project.

\section{g) Strategic value and Replication of BMP Project}

In addition to addressing the identified, important IWRM thematic issues in the country, a good IWRM BMP project should also need a strong strategic value and can be easily replicated in other representative areas. The possible indicators of the strategic value of a proposed BMP project are the potential impacts on key decision-makers, ease of applicability of the project and the priority of the IWRM issues. The applicability of a BMP project for other areas can be measured by the number of representative areas in the country that have the same IWRM issues, sharing similar project, site and stakeholder characteristics as the BMP project.

\subsection{TREND OF RIVER WATER QUALITY INDEX OF BMPs PROJECTS}

\section{Overview of Water Quality Index}

Understanding the natural evolution of water under the process of natural water circulation combined with knowledge about the background area is necessary in order to protect the value of water resource. Hence, Radojevic and Bashkin Mukhtar in (Mokhtar, 2009) together with Fulazzaky et al., (2010) concluded that in order to find adequate supplies to maintain a high quality of fresh water in the required quantity at selected places, a holistic approach for water quality monitoring and resources management is fundamental.

In addition, Changmin and Xiaoyan in (Radojevic and Baskin, 2007) also highlighted that apart from riverbed, river ecosystem and runoff, water quality should be noted as important criteria in order to value the river systems environments. Therefore, since the degradation of water quality in surface water and rivers has become an important issue in Malaysia (Faridah et.al., 2012), this section presents an evaluation of the river water quality of selected Best Management Practices (BMPs) Projectslike Sungai Langat, Sungai Melaka, Sungai Miri and Sungai Trusan, Sarawak by using the Water Quality Index (WQI)

In Malaysia, Department of Environment (DOE) classifies the rivers quality status based on a water quality index (WQI) (Malaysia Environmental Quality Report, 2010). This index can be well-defined as a technique to encapsulate bulky amounts of data water quality in simple terms so that it can be constantly being reported to the management and also the public. Apart from that, a WQI also allows for comparisons to be made between different rivers (Sharma et.al., 2014). By using a WQI, six chemical parameters are measured as a standard to determine the water quality that include $\mathrm{pH}$, Biochemical Oxygen Demand (BOD), Chemical Oxygen Demand (COD), Ammonical Nitrogen (AN), Suspended Solids (SS) and Dissolved Oxygen (DO) [38]. Besides, water quality data were also being used to determine the status of water quality, whether categorized as clean waters $(80-100)$, slightly polluted waters $(60-<80)$ or very polluted waters $(<60)$ and to classify the rivers in Class I, II, III, IV or V based on the existing Water Quality Index (WQI) as shown in Table 3 (Nony et. Al., 2009).

Table 3 General rating scale for Water Quality Index (WQI) and uses

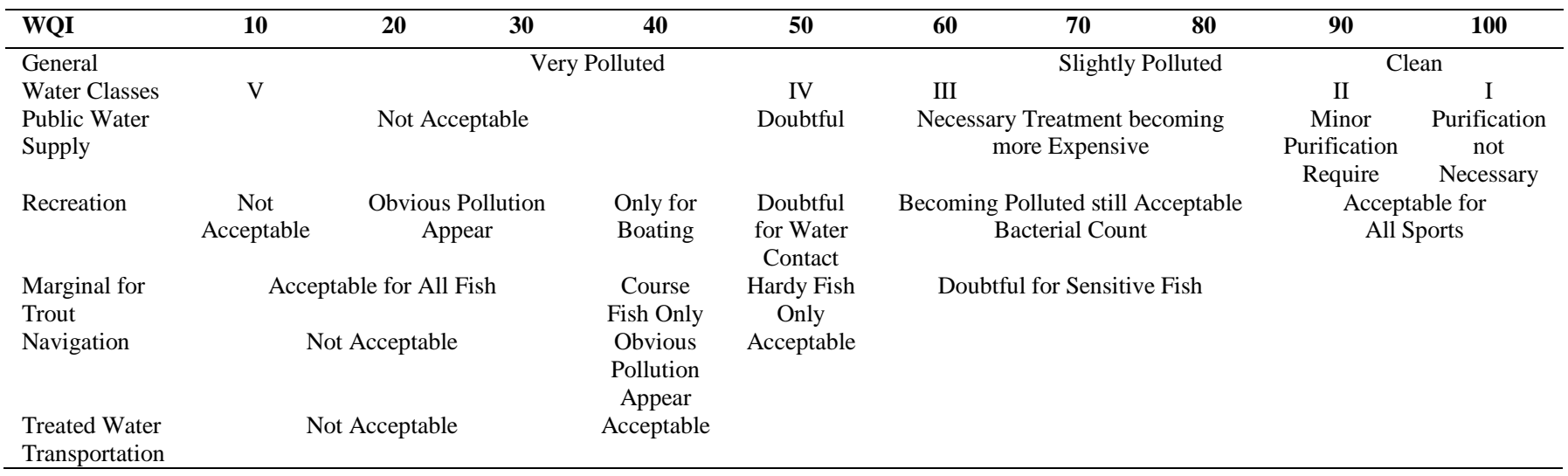

\section{Analysis of River Water Quality Index Trend ofSelected BMPs Projects}

In this section, an analysis of River Water Quality Index trend of selected BMPs Projects was being presented as demarcated in Figure 1. 12 year period of data from 2002 until 2014 were collected from Malaysia Environmental Quality Report (2002) until Malaysia Environmental Quality Report (2014) and being analyzed using content analysis technique. 12 year period has been selected as the time frame of this study due to several reasons which are; 
a) The starting time frame of 2002 :

IWRM was actively implemented in Malaysia formally in legal management.

b) The middle time frame of 2009-2012:

Best Management Practices (BMPs) Projects were implemented during this four years' time frame.

c) The ending time frame of 2014:

Currently, water quality data from the Malaysia Environmental Report, Department of Environment for the years of 2015 and 2016 was not published yet.

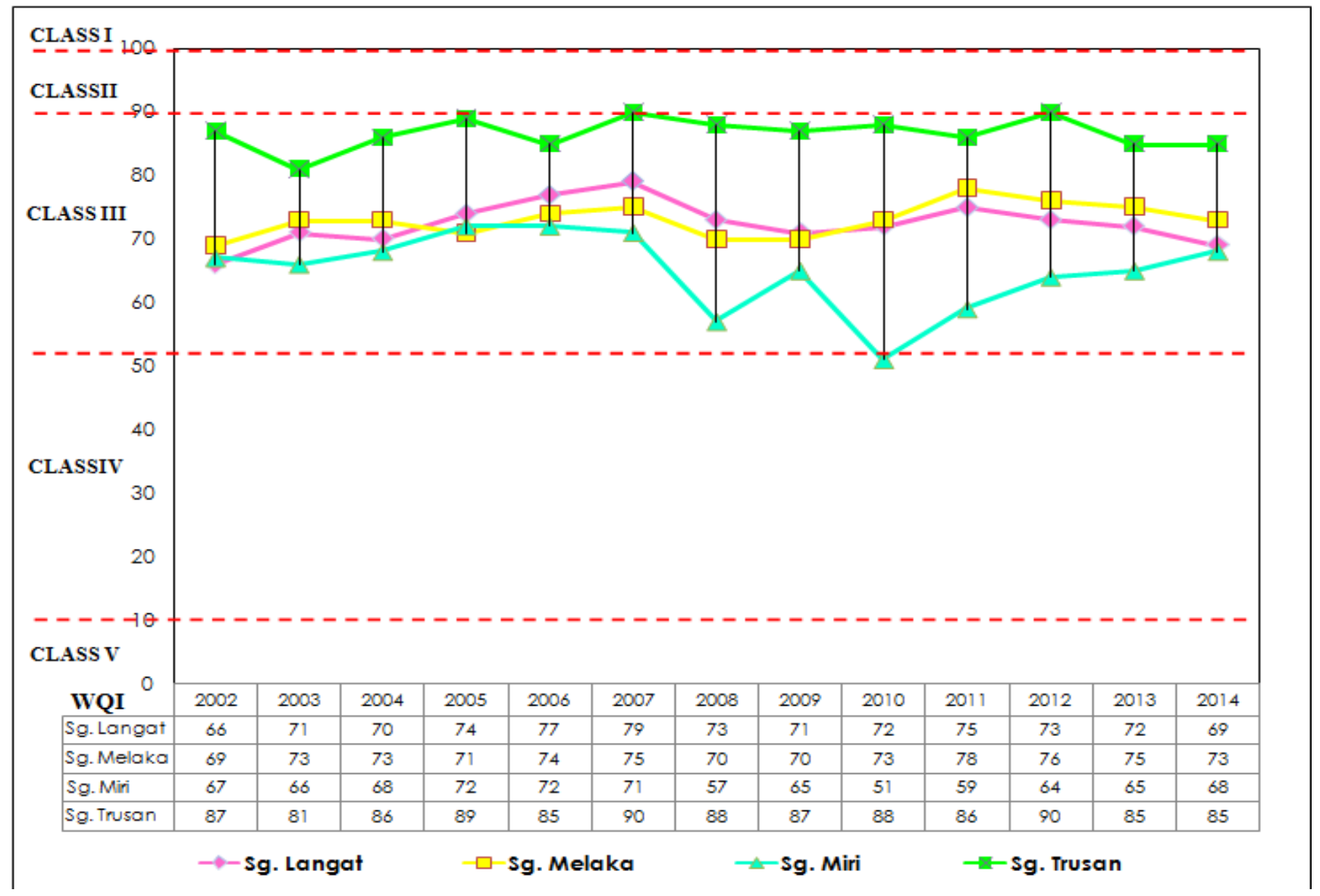

Figure 1 Trend of river water quality index of selected BMPs projects from 2002-2014

\subsection{DISCUSSION}

Most of the rivers are deteriorating in water quality due to the impacts of tremendous development that Malaysia is going through. Due to that, in line with other developed countries, Malaysia adopts and implements IWRM in their water resource development and management and put a lot of efforts by conducting many policies, plans and programs to ensure that the IWRM approach can be effectively implemented.Therefore, in order to ensure the effectiveness and efficiency of IWRM implementation, Best Management Practices projects were carried out.Since to put IWRM into practice is a challenging task, especially in terms of its implementation, thus this study is conducted to identify the outcome of the BMPs project in terms of river water quality status as well as highlights its potential to be furthered for enhancing the effective implementation of IWRM in Malaysia.

From trend of the river water quality index of selected BMPs projects from 2002 until 2013 (Figure 1), the resultscan be summarized in 3 phases of comparison:

\section{2002 vs. 2014 (The Earlier vs. the Latest of IWRM Implementation)}

As shown in Figure 2, by comparing of each selected BMPs project within 2002 and 2014, the river quality status of Sungai Langat, Sungai Melaka and Sungai Miri are increased from 66 to 69, 69 to 73 and 67 to 68 . Meanwhile, for Sungai Trusan, the river quality 
status has decreased from 87 to 85 . However, all of the river in this selected BMPs project still classifies in class III which the rivers are in slightly polluted and need necessary treatment.

\section{2002 vs. 2009-2012 (The Earlier of IWRM Implementation vs. the Best Management Practices Project Implementation)}

The river quality status of Sungai Langat, Sungai Melaka and Sungai Trusan during the four years of BMPs project implementation (2009-2012) compared with the earlier of IWRM implementation (2002), shows the positives improvement. For Sungai Langat, the river water quality increased from $66,73,78$ and 76 . While $\mathrm{Sg}$ Trusan also give the same impact from 87 to $87,88,86$ and 90 as shown in Figure 3. While both of Sungai Langat and Sungai Melaka is still in slightly polluted and classifies in class III, Sungai Trusan has achieved into clean river and classified as class II. Unfortunately, for Sungai Miri, during the implementation of BMPs project, in 2010 and 2011, the river turns to polluted and its quality status has dropped into class IV which any public water supply is doubtful for being treated. Luckily, in 2012, the river quality status improve from 55 to 64 and the class of water comes back to class III.

\section{2009-2012 vs. 2014 (The Best Management Practices Project Implementation vs. the Latest of IWRM Implementation)}

As shown in Figure 4, by comparing of each selected BMPs project within the project implementation from 2009 until 2012 with 2014, the river quality status of Sungai Langat, Sungai Melaka and Sungai Trusan have decreased from 73 to 72 and 69, 76 to 75, 73 and 90 to 85 . Meanwhile, for Sungai Miri, the river quality status increased from 64 to 65 and 68 . In overall, the water classes of these rivers are in class III and need necessary treatment due to its slightly polluted condition.

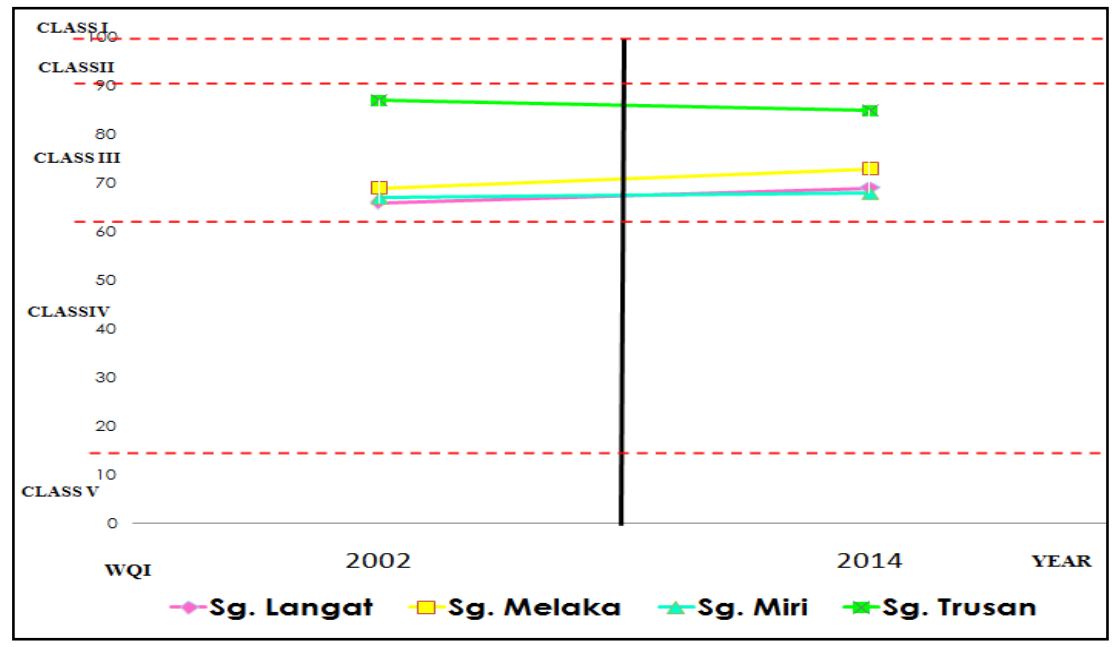

Figure 2 Comparisons of selected BMPs projects within 2002 and 2014
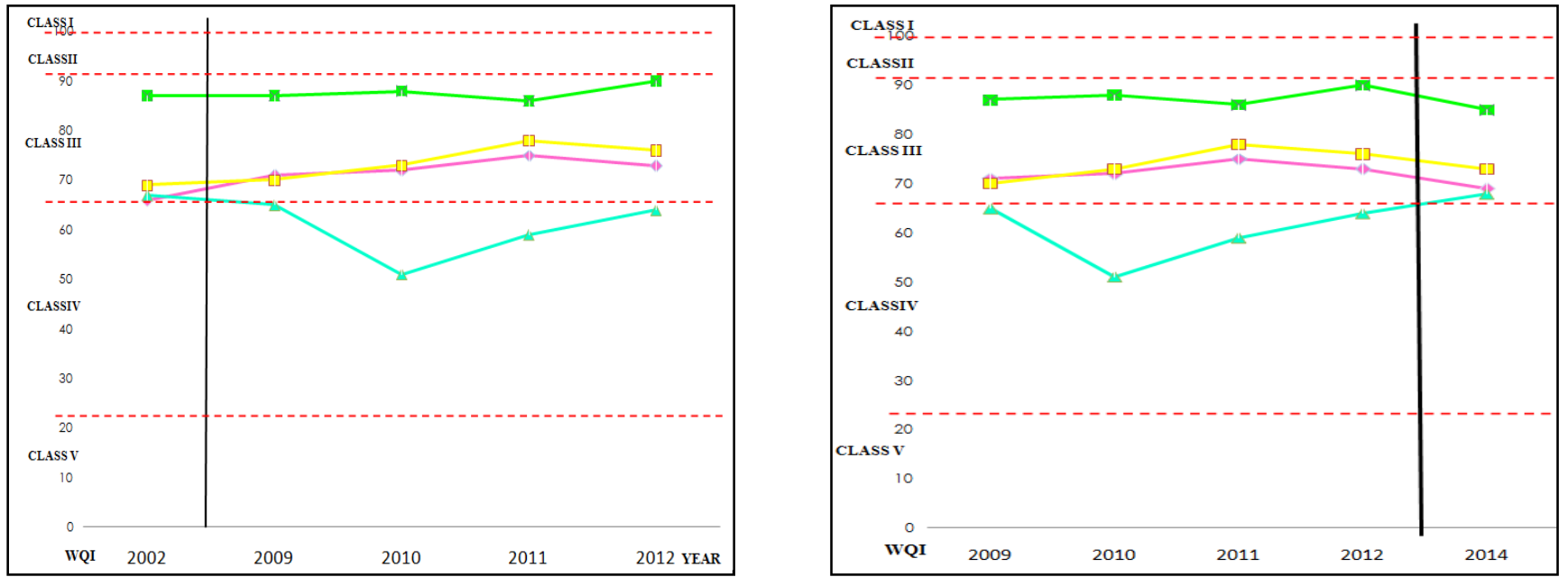

Figure 3 Comparisons of Selected BMPs Projects within 2002 and 2009-2012

Figure 4 Comparisons of Selected BMPs Projects within 2009-2012 and 2014 


\subsection{CONCLUSION}

From the finding, generally, there are differences on the river water quality trend before and after BMPs Project have been carried out from 2009 until 2012 compared to IWRM earlier implementation. During BMPs Project implementation, there have been improvements in river water quality status in three out of four river selected. However, after BMPs Project implementation has been ended, the river water quality status seems to be decreasing. Generally, BMPs Project should be highly encouraged because it asserts that there is a technique, method, process, activity, incentive or reward that is more effective at delivering a particular outcome than any other technique, method and process. The idea is that with proper processes, checks, and testing, a desired outcome can be delivered with fewer problems and unforeseen complications.

From the result, the studies revealed that, the Best Management Practice projects have a potential in improving water quality and this project can minimize IWRM issues as well as enhancing the implementation. However, since the effectiveness of BMPs projects in enhancing IWRM implementation, especially in terms of water quality might be a slow progress, the stakeholder should find the best methodology and approach to ensure the successful of its implementation since the stakeholders and community participation hold the key to the effective implementation of IWRM. In fact,

Therefore, in order to obtain a better outcome in the future, further work can be done. Since case studies help water managers learn about best practices and understand the lessons learned, thus, Best Management Practice (BMPs) Project should be actively promoted among water resource stakeholders through attention to the criteria highlighted in this paper and through development of measurable indicators of success. Besides, this study also encourage that there is a need to disseminate and enrich understanding and awareness of the use of IWRM-based concepts in formulating BMPs programs. By that, it is hoped that Best Management Practice (BMPs) Project can enhance the progress toward IWRM implementation that holds the promise to sustain ecological, economic, and social resources for citizens today and into the future.

\section{Acknowledgement}

We are grateful for the partial funding of this study is made possible through the research grant obtained from Research University Grant (RUG) PY/2014/03702.

\section{References}

Aris, A. Z., Lim, W. Y., Praveena, S. M., Yusoff, M. K., Ramli, M. F. and Juahir, H. (2014). Water Quality Status of Selected Rivers in Kota Marudu, Sabah, Malaysia and its Suitability for Usage. Sains Malaysiana, 43(3), 377-388.

Bao, J. L. K. Water Quality Study And Its Relationship With High Tide And Low Tide At Kuantan River. Doctoral dissertation. Universiti Malaysia Pahang; 2010. Buller, H. (1996). Towards Sustainable Water Management: Catchment Planning in France And Britain. Land Use Policy, 13(4), $289-302$.

Donoso, G. and Cancino, J. (2010). Contribution of Integrated Water Resources Management Towards The Achievement of the Millennium Development Goals (MDGs). Economia Agraria, 14, 65-78.

Faridah, O., AlaaEldin, M. E., and Ibrahim, M. 2012.Trend Analysis Of A Tropical Urban River Water Quality in Malaysia. Journal of Environmental Monitoring, 14, 3164-3173.

Fulazzaky, M. A., Seong, T. W. and Masirin, M. I. M. (2010). Assessment of water quality status for the Selangor River in Malaysia. Water, Air, \& Soil Pollution, 205(1), 63-77.

Gasim, M. B., Ismail, B. S., Toriman, E., Mir, S. I. and Chek, T. C. (2007). A Physico-Chemical Assessment of the Bebar River, Pahang, Malaysia. Global Journal of Environmental Research, 1(1): 7-11.

Global Water Partnership. (2004). Informal Stakeholder Baseline Survey: Current Status of National Efforts to Move Towards Sustainable Water Management Using an IWRM Approach. Global Water Partnership, Stockholm, Sweden: www.gwpforum.org.

Kua, H. W. (2007). Information Flow and Coherently Integrated Policy Making for Promoting Energy Efficiency. Environmental Science and Technology, 41(9), 3047-3054.

Liu, C. and Liu, X. (2009). Healthy river and its indication, criteria and standards. Journal of Geographical Sciences, 19(1), 3-11.

Malaysia Environmental Quality Report 2013. Department of Environment (DOE), Ministry of Natural Resources and Environment, Kuala Lumpur, Malaysia. Malaysia Environmental Quality Report 2002. Department of Environment (DOE), Ministry of Natural Resources and Environment, Kuala Lumpur, Malaysia Malaysia Environmental Quality Report 2003. Department of Environment (DOE), Ministry of Natural Resources and Environment, Kuala Lumpur, Malaysia. Malaysia Environmental Quality Report 2004. Department of Environment (DOE), Ministry of Natural Resources and Environment, Kuala Lumpur, Malaysia. Malaysia Environmental Quality Report 2005. Department of Environment (DOE), Ministry of Natural Resources and Environment, Kuala Lumpur, Malaysia. Malaysia Environmental Quality Report 2006. Department of Environment (DOE), Ministry of Natural Resources and Environment, Kuala Lumpur, Malaysia. Malaysia Environmental Quality Report 2007. Department of Environment (DOE), Ministry of Natural Resources and Environment, Kuala Lumpur, Malaysia. Malaysia Environmental Quality Report 2008. Department of Environment (DOE), Ministry of Natural Resources and Environment, Kuala Lumpur, Malaysia. Malaysia Environmental Quality Report 2009. Department of Environment (DOE), Ministry of Natural Resources and Environment, Kuala Lumpur, Malaysia. Malaysia Environmental Quality Report 2010. Department of Environment (DOE), Ministry of Natural Resources and Environment, Kuala Lumpur, Malaysia. Malaysia Environmental Quality Report 2011. Department of Environment (DOE), Ministry of Natural Resources and Environment, Kuala Lumpur, Malaysia. Malaysia Environmental Quality Report 2012. Department of Environment (DOE), Ministry of Natural Resources and Environment, Kuala Lumpur, Malaysia. Malaysia Environmental Quality Report 2014. Department of Environment (DOE), Ministry of Natural Resources and Environment, Kuala Lumpur, Malaysia.

Margerum, R. D. and Hooper. B. P. (2001). Integrated Environmental Management: Improving Implementation Through Leverage Point Mapping. Society and Natural Resources, 14(1), 1-19.

Medema, W., Brian. S., McIntosh, B. S. and Jeffrey, P. J. (2008). From Premise to Practice: A Critical Assessment of Integrated Water Resources Management Approaches in the Water Sector. Ecology and Society, 13(2), 29.

Mokhtar, M. B., Aris, A. Z., Abdullah, M. H., Yusoff, M. K.,Abdullah, M., Idris, A. R. and Raja Uzir, R. I. (2009). A pristine environment and water quality in perspective: Maliau Basin,Borneo's mysterious world. Water and Environment Journal, 23(3), 219-228.

Muyibi, S. A., Ambali, A. R. and Eissa, G. S. (2008). The Impact Of Economic Development On Water Pollution: Trends and Policy Actions in Malaysia. Water Resources Management, 22(4), 485-508.

Nik, A. S. B. and Asia, P. E. C. S. B. Volume 1: National IWRM Need Assessment Survey.. National Study For The Effective Implementation Of Integrated Water Resources Management In Malaysia. Kuala Lumpur: JabatanPengairandanSaliran, 51-53:2008a.

Nik, A. S. B. and Asia, P. E. C. S. B. Volume IV: Best Management Practices. National Study For The Effective Implementation Of Integrated Water Resources Management In Malaysia. Kuala Lumpur: JabatanPengairandanSaliran, 150-152:2008b. 
Nik, A. S. B. and Asia, P. E. C. S. B. Volume IV: Best Management Practices. National Study For The Effective Implementation Of Integrated Water Resources Management In Malaysia. Kuala Lumpur: JabatanPengairandanSaliran, 16-18:2008c.

Nik, A. S. B. and Asia, P. E. C. S. B.Main Report: Best Management Practices. National Study For The Effective Implementation Of Integrated Water Resources Management In Malaysia. Kuala Lumpur: Jabatan Pengairandan Saliran, 13:2008d.

Nik, A. S. B. and Asia, P. E. C. S. B.Volume IV: Best Management Practices. National Study For The Effective Implementation Of Integrated Water Resources Management In Malaysia. Kuala Lumpur: JabatanPengairandanSaliran, 84-86:2008e.

Nik, A. S. B. and Asia, P. E. C.S.B. Volume IV: Best Management Practices. National Study For The Effectiive Implementation Of Integrated Water Resources Management In Malaysia. Kuala Lumpur: JabatanPengairandan Saliran, 1:2008f.

Nik, A. S. B. and Asia, P. E. C.S.B.Volume IV: Best Management Practices. National Study For The Effective Implementation Of Integrated Water Resources Management In Malaysia. Kuala Lumpur: Jabatan Pengairandan Saliran, 93-94:2008g.

Nik,A.S.B. and Asia, P. E. C. S. B.Volume IV: Best Management Practices. National Study For The Effective Implementation Of Integrated Water Resources Management In Malaysia. Kuala Lumpur: JabatanPengairandanSaliran, 123-125:2008h.

Nony, C., Feona, I., Lee. K. H., and Kawi, B. 2013. Water quality status of Liwagu River, Tambunan, Sabah, Malaysia. Journal of Tropical Biology And Conservation, 10, 67-73.

Othman, F., AlaaEldin, M. E. and Mohamed, I. (2012).Trend Analysis Of A Tropical Urban River Water Quality in Malaysia. Journal of Environmental Monitoring, 14(12), 3164-3173

Radojevic, M. and Bashkin, V. N. (2007). Practical EnvironmentalAnalysis. United Kingdom: Royal Society of Chemistry

Rahaman, M. M., and Varis, O. (2005). Integrated Water Resources Management; Evolution, Prospects and Future Challenges. Sustainability: Science, Practice and Policy, 1(1), 11-8

Sharma, M. K., Jain, C. K. and Singh, O. (2014). Characterization Of Point Sources And Water Quality Assessment Of River Hindon Using Water Quality Index.Journal of Indian Water Resources Society, 34(1), 53-64.

Shuhaimi-Othman, M., Lim, E. and Mushrifah, I. (2007). Water Quality Changes in Chini Lake, Pahang, West Malaysia. Environmental Monitoring and Assessment, 131(1), 279-292.

Sukereman, A. S., and Suratman, R. (2014). The Needs for Integrated Water Resource Management (IWRM) Implementation Progress Assessment in Malaysia. International Journal of Innovation, Management and Technology, 5(6), 479-482.

Suratman, S., Ali, A. and Ting, L. T. (2005). Penilaian indeks kualiti air di Lembangan Sungai Ibai, Terengganu. SainsMalaysiana, 34(2), 55-59.

Suratman, S., Awang, M., Ling, L. A. and Tahir, N. M. (2009). Kajian indeks kualiti air di Lembangan Sungai Paka, Terengganu. Sains Malaysiana, 38(2), 125-131.

Svendsen, M. (2005), Irrigation and River Basin Management Options for Governance and Institutions, Cambridge, IWMI CABI Publishing.

Sonoda, T (2009). Introduction to IWRM Guidelines at River Basin Level.United Nations Educational,Scientific and Cultural Organization,Paris, France.

UNEP 2012. The UN-Water Status Report on the Application of Integrated Approaches to Water Resources Management.

Varis, O., Kummu, M., Keskinen, M., Sarkkula, J., Koponen, J., Heinonen, U. and Makkonen, K. (2006). Integrated Water Resources Management on Tonle Sap Lake, Cambodia.Water Science, Technology:water Supply, 6(5), 51-58.

Wongprasong, T. Integrated Water Resources Management in theMekong, 2007. Australian Mekong Resource Centre.

Yusof, A. M., Mahat, M. N., Omar, N. and Wood, A. K. H. (2001). Water Quality Studies In An Aquatic Environment Of Disused Tin-Mining Pools And In Drinking Water. Ecological Engineering, 16(3), 405-414. 